\title{
Determinan Kinerja Pasar Saham Dengan Risk Premium Sebagai Variabel Intervening Pada Bank Indonesia (BI)
}

\author{
Silvia Sari ,Lucy Aprelia D, Lusiana \\ Universitas Putra Indonesia YPTK Padang, Indonesia \\ Email :lucyaprelia95@gmail.com
}

\begin{abstract}
The purpose of this study was to determine the effect of interest rate, money supply and inflation rate on stock market performance. This study consists of three independent variables, namely interest rate, money supply and inflation rate. The dependent variable is stock market performance. And one intervening variable risk premium. The analytical method used is multiple linear regression analysis and path analysis. Methods of data collection in this research is to use the internet research to obtain secondary data by accessing the website www.bi.go.id. he results obtained show that there is an effect of interest rate risk premiums. Money supply has no effect on risk premiums. Inflation rate affects the risk premium. And interest rate, money supply, inflation rate together has an effect on the risk premium. Interest rate affects stock market performance. Money supply has no effect on stock market performance. The inflation rate has no effect on stock market performance. Risk premium affects stock market performance. And interest rate, money supply, inflation rate and risk premium affect the stock market performance. Risk premium cannot mediate the effect of interest rates on stock market performance. Risk premium cannot mediate the effect of money supply on stock market performance. Risk premium can mediate the effect of inflation rate on stock market performance.
\end{abstract}

Keywords: Interest Rate, Money Supply, Inflation Rate, Stock Market Performance, Risk Premium

\section{Pendahuluan}

Di Indonesia saat ini keberhasilan suatu perusahaan sangat ditentukan oleh stock market performance. Stock market performance itu sendiri menunjukkan sebuah totalitas, akumulasi, resultan dari keseluruhan kinerja masing-masing saham yang tercatat dan diperdagangkan di Bursa Efek Indonesia (BEI). Dalam hal ini stock market performance diwakili oleh Indeks Harga Saham Gabungan (IHSG). Jika IHSG naik berarti kinerja pasar baik, dan jika IHSG turun berarti kinerja pasar juga sedang merosot. Indeks Harga Saham Gabungan (IHSG) merupakan suatu nilai untuk mengukur kinerja saham yang tercatat di suatu bursa efek. Indeks Harga Saham Gabungan (IHSG) di Bursa Efek Indonesia meliputi pergerakan-pergerakan harga untuk saham biasa dan saham preferen (Pamungkas \& Darmawan, 2018). Indeks Harga Saham Gabungan (IHSG) merupakan indeks yang menggunakan semua perusahaan tercatat sebagai komponen perhitungan indeks. Bursa Efek Indonesia berwenang mengeluarkan dan atau tidak memasukkan satu atau beberapa perusahaan tercatat dari perhitungan IHSG (Sari, 2019). Berikut data IHSG yang tercatat di Bursa Efek Indonesia:

Tabel 1 Data IHSG Tahun 2019 (Per Bulan)

\begin{tabular}{ccc} 
No & Bulan & IHSG (\%) \\
\cline { 2 - 3 } 1 & Januari & $5,46 \%$ \\
\hline 2 & Februari & $4,02 \%$ \\
\hline 3 & Maret & $4,43 \%$ \\
\hline 4 & April & $4,21 \%$ \\
\hline 5 & Mei & $0,24 \%$ \\
\hline 6 & Juni & $2,65 \%$ \\
\hline 7 & Juli & $3,16 \%$ \\
\hline 8 & Agustus & $2,16 \%$ \\
\hline 9 & September & $0,41 \%$ \\
\hline 10 & Oktober & $0,55 \%$ \\
\hline 11 & November & $2,95 \%$ \\
\hline 12 & Desember & $1,70 \%$
\end{tabular}

Sumber: idx.co.id 
Data di atas menunjukkan bahwa IHSG pada bulan Januari sebesar 5,46\% mengalami penurunan pada bulan Februari menjadi $4,02 \%$ dan kembali meningkat pada bulan Maret $4,43 \%$, kemudian menurun lagi pada bulan April 4,21\%, dan terus menurun pada bulan Mei menjadi $0,24 \%$, kembali meningkat pada bulan Juni 2,65\%, bulan Juli 3,16\%, dan pada bulan Agustus menurun kembali menjadi 2,16\%, terus menurun pada bulan September 0,41\%, sedikit meningkat pada bulan Oktober $0,55 \%$, terus meningkat untuk bulan November menjadi 2,95\% dan pada akhir tahun kembali menurun menjadi 1,70\%.

Menurut Bank Indonesia interest rate atau BI rate adalah interest rate yang di umumkan kepada publik sebagai kebijakan moneter yang di tetapkan oleh Bank Indonesia yang mencerminkan sikap atau stance. Interest rate juga mempengaruhi fluktuasi harga saham di bursa efek. Penurunan IHSG yang menyebabkan investor lebih suka menabung di bank dengan kenaikan interest rate yang signifikan bisa memperkuat Rupiah. Ketika interest rate mengalami penurunan maka harga saham akan mengalami peningkatan. Begitu juga sebaliknya jika interest rate mengalami peningkatan maka harga saham akan mengalami penurunan. Karena dengan kondisi IHSG mengalami peningkatan maka investor akan lebih senang berinvestasi pada pasar modal karena interest rate mengalami penurunan. Dan Rupiah akan melemah dengan tingginya interest rate (Harsono \& Worokinasih, 2018).

Faktor makro ekonomi lainnya yang juga mempengaruhi harga saham yaitu money supply yang sering disebut sebagai uang beredar yang menurut Bank Indonesia merupakan suatu kewajiban sistem moneter (Bank Sentral, Bank Umum, dan Bank Perkreditan Rakyat (BPR) terhadap sektor swasta domestik (tidak termasuk pemerintah pusat dan bukan penduduk) (Anggarini, 2016). Money supply merupakan jumlah uang yang saat ini dipegang oleh masyarakat, biasanya bila perekonomian tumbuh dan berkembang, maka money supply juga bertambah, sedangkan komposisinya berubah (Noviandi, et al., 2017). (Altintas \& Yacouba, 2018) menyebutkan bahwa penurunan harga saham dan penurunan money supply yang menghasilkan peningkatan stok harga disebabkan oleh peningkatan money supply.

Pemerintah dalam pengaturan money supply salah satunya dengan memperhatikan inflation rate. Inflation rate terjadi ketika hampir semua barang yang ada di pasar meningkat terus menerus yang menyebabkan masyarakat cenderung tidak ingin membeli barang (Augustpaosa Nariman, 2019). Inflation rate dapat dikatakan sebagai kecenderungan terjadinya kenaikan harga setiap produk yang beredar di masyarakat secara keseluruhan. Harga saham akan dipengaruhi oleh inflation karena adanya penurunan pendapatan, kekayaan, dan efisiensi produksi (Kumalasari et al., 2016).

\section{Tinjauan Pustaka}

\subsection{Stock Market Performance}

Menurut (Nurhayati, 2017) market performance merujuk pada penilaian kinerja perusahaan oleh pasar yang tercermin dari nilai sebuah perusahaan berdasarkan jumlah saham yang beredar dikalikan dengan perhitungan harga saham. Untuk menilai kinerja perusahaan dapat dilihat dari nilai lebih yang dimiliki dan kecenderungan yang tercermin dari laporan tahunan perusahaan. Dalam mengukur kinerja perusahaan di sini dapat menggunakan metode Tobin's Q dengan standar pengukurannya Q Ratio. Metode perhitungannya :

$$
\text { Kinerja Pasar }=\frac{\text { Market Value Of Equity }+ \text { Total Liabilities }}{\text { Total Assets }}
$$

Menurut Robert Ang dalam (Wongkar et al., 2018) menyatakan bahwa suatu nilai yang digunakan untuk mengukur kinerja pasar saham (stock market performance) dapat menggunakan Indeks Harga Saham Gabungan (IHSG). Formula yang digunakan untuk menghitung IHSG yaitu:

\section{2}

$$
I H S G=\frac{\Sigma p x}{d} \times 100
$$

\section{Interest Rate}

Interest rate atau yang sering disebut sebagai suku bunga merupakan jumlah uang yang harus dibayarkan oleh kreditur kepada debitur dalam bentuk persentase yang biasanya 
dibayarkan dalam per unit waktu. Menurut Arifin dalam (Noviandi et al., 2018) suku bunga (SBI) yaitu pengontrolan perekonomian Nasional atau mengontrol peredaran uang di masyarakat dengan menaikkan tingkat suku bunga yang diberlakukan oleh Bank Indonesia (SBI) pemerintah melalui BI. Suku bunga dapat dihitung dengan menggunakan rumus sebagai berikut:

$$
\text { Suku Bunga }=\frac{(\text { Vol } 1 \times \text { Rate } 1)+(\text { Vol2 } \times \text { Rate } 2)+(\text { VolN } \times \text { RateN })}{\text { Total Volume }}
$$

\subsection{Money Supply}

Menurut Rahardja dan Manurung dalam (Anggarini, 2016) menyatakan bahwa jumlah uang beredar (money supply) merupakan keseluruhan uang yang berada di tangan masyarakat. Persamaan jumlah uang beredar dinyatakan dalam:

Jumlah uang beredar

$$
=\text { uang primer (monetary base) } x \text { pengganda uang (money multiplier) }
$$

\subsection{Inflation Rate}

Menurut (Rachmawati, 2019) inflasi (inflation) merupakan indikator ekonomi yang menyebabkan kenaikan harga suatu barang atau jasa dalam suatu periode tertentu. Dengan adanya inflasi yang tinggi akan menyebabkan naiknya biaya produksi suatu barang dan jasa yang akan di pasarkan. Tingkat infalasi dapat dihitung dengan:

\section{Tingkat Inflasi $=$ IHK Periode $n-I H K$ tahun sebelumnya}

\subsection{Risk Premium}

Menurut (Yuwana, 2019) risk premium merupakan instrumen investasi yang berisiko dengan risk premium sebagai tambahan returnnya. Untuk menghitung risk premium pada Indeks Harga Saham Gabungan (IHSG) dapat menggunakan rumus:

$$
E R P=\text { return } I H S G-\text { risk free rate }
$$

\subsection{Kerangka Fikir}

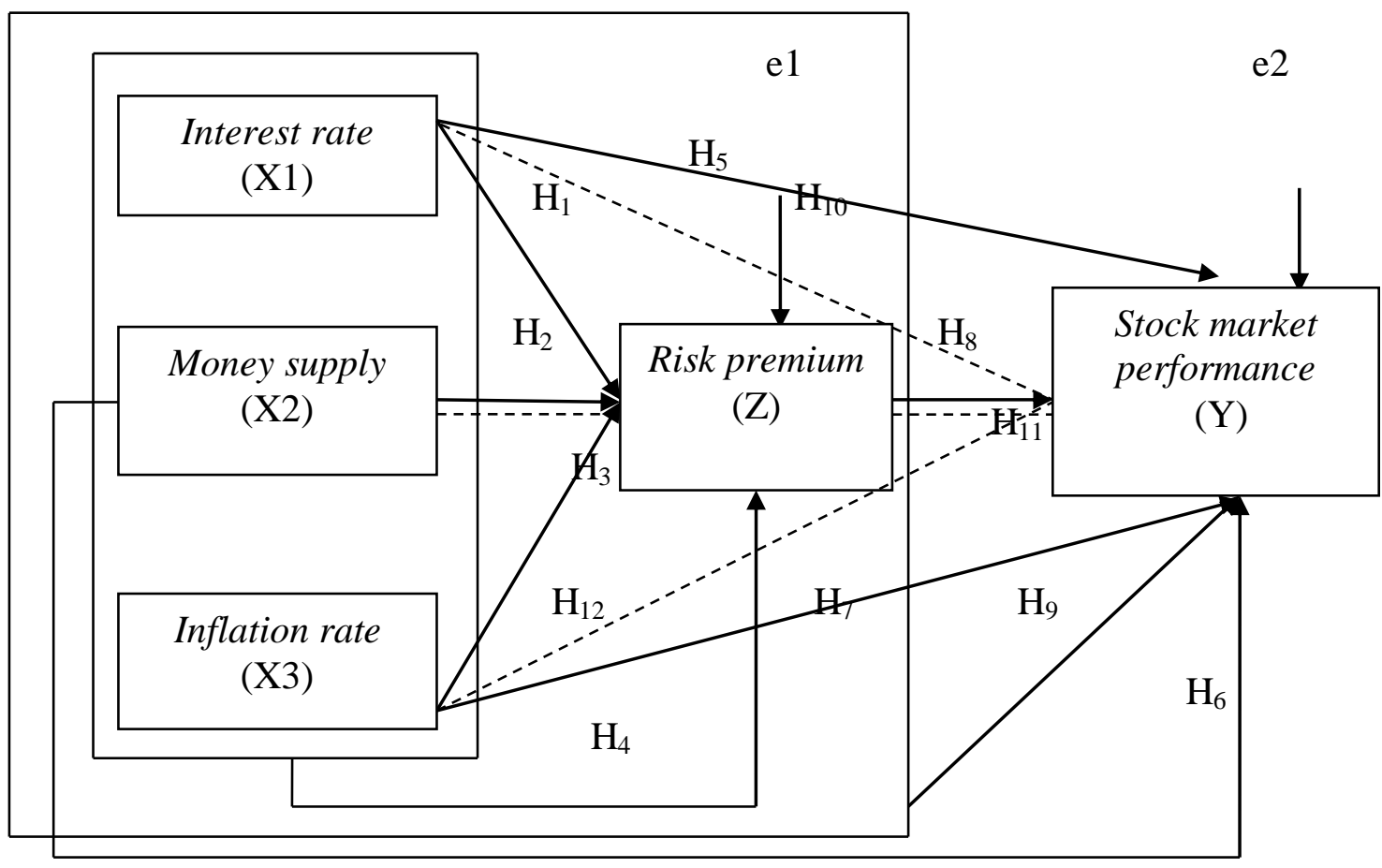

Gambar 1 Kerangka Fikir 


\subsection{Pengembangan Hipotesis}

Hipotesis merupakan dugaan sementara dari perumusan masalah. Berdasarkan pada landasan teori dan kerangka pemikiran di atas, maka dapat dibuat suatu hipotesis atau dugaan sementara yang mendukung pemecahan masalah tersebut sebagai berikut:

\subsubsection{Pengaruh Interest Rate terhadap Risk Premium pada Bank Indonesia (BI).}

Interest rate merupakan pengontrolan perekonomian Nasional atau mengontrol peredaran uang di masyarakat dengan menaikkan tingkat suku bunga yang diberlakukan oleh Bank Indonesia (SBI) pemerintah melalui BI (Noviandi et al., 2018).

Penelitian yang dilakukan oleh (Yuwana, 2019) menunjukkan bahwa suku bunga (interest rate) tidak memiliki pengaruh yang signifikan terhadap risk premium. Berdasarkan uraian tersebut dapat dirumuskan hipotesis sebagai berikut:

$\mathrm{H}_{1}$ : Diduga interest rate berpengaruh terhadap risk premium pada Bank Indonesia (BI).

\subsubsection{Pengaruh Money Supply terhadap Risk Premium pada Bank Indonesia (BI).}

Money supply menurut Bank Indonesia merupakan suatu kewajiban sistem moneter ( Bank Sentral, Bank Umum, dan Bank Perkreditan Rakyat (BPR)) terhadap sektor swasta domestik (tidak termasuk pemerintah pusat dan bukan penduduk) (Anggarini, 2016).

Dari hasil penelitian (Yuwana, 2019) menyatakan money supply (M2) menunjukkan hasil yang signifikan positif, artinya semakin money supply (M2), maka semakin tinggi juga nilai risk premium. Berdasarkan uraian tersebut dapat dirumuskan hipotesis sebagai berikut:

$\mathrm{H}_{2}$ : Diduga money supply berpengaruh terhadap risk premium pada Bank Indonesia (BI).

\subsubsection{Pengaruh Inflation Rate terhadap Risk Premium pada Bank Indonesia (BI).}

Inflation rate merupakan suatu kondisi yang menggambarkan situasi dan kejadian di mana harga yang lazim disebut sebagai inflasi merupakan suatu kondisi yang menggambarkan situasi dan kejadian di mana mata uang mengalami pelemahan dan harga barang mengalami kenaikan. Dalam penelitian (Yuwana, 2019) inflasi tidak memiliki pengaruh yang signifikan terhadap risk premium. Berdasarkan uraian tersebut dapat dirumuskan hipotesis sebagai berikut:

$\mathrm{H}_{3}$ : Diduga inflation rate berpengaruh terhadap risk premium pada Bank Indonesia (BI).

2.7.4 Pengaruh Interest Rate, Money Supply, Inflation Rate secara bersama-sama terhadap Risk Premium sebagai variabel intervening pada Bank Indonesia (BI).

Risk premium dinyatakan sebagai return tambahan yang dipilih investor untuk berinvestasi di portofolio pasar yang berisiko dari pada aset bebas risiko. Risk premium menunjukkan risiko yang ditanggung investor atas saham yang dimiliki. Sejalan dengan prinsip dasar investasi, semakin tinggi risiko yang didapatkan, maka semakin tinggi pula tingkat pengembalian yang diharapkan (Rizqiyana dan Arfianto, 2019). Penelitian terdahulu (Rizqiyana dan Arfianto, 2019) dalam penelitiannya menunjukkan market risk premium berpengaruh positif terhadap return saham. Berdasarkan uraian tersebut dapat dirumuskan hipotesis sebagai berikut: $\mathrm{H}_{4}$ : Diduga interest rate, money supply, inflation rate secara bersama-sama berpengaruh terhadap risk premium pada Bank Indonesia (BI).

\subsection{Hipotesis}

$\mathrm{H}_{1} \quad$ :Diduga interest rate berpengaruh terhadap risk premium pada Bank Indonesia (BI).

$\mathrm{H}_{2} \quad$ :Diduga money supply berpengaruh terhadap risk premium pada Bank Indonesia (BI).

$\mathrm{H}_{3} \quad$ :Diduga inflation rate berpengaruh terhadap risk premium pada Bank Indonesia (BI).

$\mathrm{H}_{4} \quad$ :Diduga interest rate, money supply, inflation rate secara bersama-sama berpengaruh terhadap risk premium pada Bank Indonesia (BI).

$\mathrm{H}_{5} \quad$ :Diduga interest rate berpengaruh terhadap stock market performance pada Bank Indonesia (BI). 
$\mathrm{H}_{6} \quad$ :Diduga money supply berpengaruh terhadap stock market performance pada Bank Indonesia (BI).

$\mathrm{H}_{7} \quad$ :Diduga inflation rate tidak berpengaruh terhadap stock market performance pada Bank Indonesia (BI).

$\mathrm{H}_{8} \quad$ :Diduga risk premium berpengaruh terhadap stock market performance pada Bank Indonesia (BI).

$\mathrm{H}_{9} \quad$ :Diduga interest rate, money supply, inflation rate dan risk premium secara bersamasama berpengaruh terhadap stock market performance pada Bank Indonesia (BI).

$\mathrm{H}_{10}$ :Diduga interest rate berpengaruh terhadap stock market performance melalui risk premium sebagai variabel intervening pada Bank Indonesia (BI).

$\mathrm{H}_{11}$ :Diduga money supply berpengaruh terhadap stock market performance melalui risk premium sebagai variabel intervening pada Bank Indonesia (BI).

$\mathrm{H}_{12}$ :Diduga inflation rate berpengaruh terhadap stock market performance melalui risk premium sebagai variabel intervening pada Bank Indonesia (BI).

\section{Metodologi Penelitian}

Penelitian ini dilakukan pada perusahaan LQ45 yang terdaftar di Bursa Efek Indonesia, dengan mengambil data sekunder yang bersifat kuantitatif, yang telah dipublikasikan dalam website (www.bi.go.id) periode tahun 2015-2019.

\subsection{Populasi}

Menurut (Sugiyono, 2016:80) populasi adalah wilayah generalisasi yang terdiri atas, obyek/subyek yang mempunyai kualitas dan karakteristik tertentu yang ditetapkan oleh peneliti untuk dipelajari dan kemudian ditarik kesimpulannya. Populasi yang akan menjadi pengamatan dalam penelitian ini adalah semua data dari Bank Indonesia (BI) pada tahun 2015-2019.

\subsection{Sampel}

Menurut (Sugiyono, 2016) sampel adalah bagian dari jumlah dan karakteristik yang dimiliki oleh populasi yang digunakan untuk penelitian. Metode pemilihan sampel dalam penelitian ini yaitu metode sampling jenuh, artinya menurut (Rachmawati, 2019) teknik penarikan sampel dengan sampling jenuh/sensus yaitu teknik penentuan sampel bila semua anggota populasi digunakan sebagai sampel.

\subsection{Teknik dan Analisis Data}

Teknik pengumpulan data merupakan langkah yang paling strategis dalam penelitian, karena tujuan utama dalam penelitian adalah mendapatkan data. Tanpa mengetahui teknik pengumpulan data maka, peneliti tidak akan mendapatkan data yang memenuhi standar yang diterapkan (Sugiyono, 2012:224) teknik pengumpulan data merupakan langkah yang paling utama dalam penelitian. Data analisis yang digunakan dalam penelitian ini adalah metode analisis statistik dengan menggunakan analisis regresi berganda dan analisis data dilakukan dengan bantuan SPSS versi 23.

\section{Hasil dan Pembahasan}

\subsection{Hasil Uji Statistik Deskriptif}

Pada pengujian deskriptif ini untuk menguji seberapa besar nilai mean, standar deviasi, nilai minimum, median dan maksimum. Tujuan dari statistik deskriptif ini untuk mengetahui seberapa besar keakuratan data dan penyimpangan pada data tersebut. Untuk lebih jelasnya dapat dilihat pada tabel di bawah ini :

Tabel 2 Hasil Analisis Statistik Deskriptif Descriptive Statistics

\begin{tabular}{|l|r|r|r|r|r|}
\hline & N & Minimum & Maximum & \multicolumn{1}{c|}{ Mean } & Std. Deviation \\
\hline Stock.Market.Performance & 60 & 42,24 & 66,61 & 56,0852 & 6,37241 \\
Risk.Premium & 60 & $-7,16$ & $-4,95$ & $-5,9682$ &, 62434 \\
Interest.Rate & 60 & 5,00 & 7,10 & 5,9717 &, 62272 \\
Money.Supply & 60 & 426361 & 6136552 & 5060451,80 & 826720,155 \\
Inflation.Rate & 60 & 2,48 & 7,26 & 3,9893 & 1,37257 \\
Valid N (listwise) & 60 & & & & \\
\hline
\end{tabular}

Sumber: Data Sekunder Diolah, 2021 
Berdasarkan tabel 2 di atas dapat diketahui bahwa secara deskriptif variabel-variabel dalam penelitian ini. Variabel stock market performance memiliki nilai rata-rata sebesar 56,0852 dengan standar deviasi sebesar 6,37241, nilai maksimum 42,24 dan nilai minimum sebesar 66,61. Variabel risk premium memiliki nilai rata-rata sebesar -5,9682 dengan standar deviasi sebesar 0,62434, nilai maksimum $-4,95$ dan nilai minimum sebesar $-7,16$. Variabel interest rate memiliki nilai rata-rata sebesar 5,9717 dengan standar deviasi sebesar 0,62272, nilai maksimum 7,10 dan nilai minimum sebesar 5,00. Variabel money supply memiliki nilai rata-rata sebesar 5.060.451,80 dengan standar deviasi sebesar 826.720,155, nilai maksimum 6.136.552 dan nilai minimum sebesar 426.361. Dan variabel inflation rate memiliki nilai ratarata sebesar 3,9893 dengan standar deviasi sebesar 1,37257, nilai maksimum 7,26 dan nilai minimum sebesar 2,48 .

\subsection{Uji Asumsi Klasik}

\subsubsection{Hasil Uji Normalitas}

Uji normalitas bertujuan untuk mengetahui apakah dalam model regresi variabel pengganggu atau residual memiliki distribusi normal atau tidak. Berikut tabel uji normalitas dengan Kolmogorov-Smirnov.

Tabel 3 One - Sample Kolmogrov-Smirnov Test One-Sample Kolmogorov-Smirnov Test

\begin{tabular}{|ll|r|}
\hline & & \multicolumn{2}{|c|}{$\begin{array}{c}\text { Unstandardized } \\
\text { Residual }\end{array}$} \\
\hline $\mathrm{N}$ & & $60^{\mathrm{c}}$ \\
Exponential parameter. ${ }^{\text {a,b }}$ & Mean & 3,8879225 \\
Most Extreme Differences & Absolute &, 227 \\
& Positive &, 128 \\
& Negative &,- 227 \\
Kolmogorov-Smirnov Z & & 1,110 \\
Asymp. Sig. (2-tailed) & &, 170 \\
\hline
\end{tabular}

Sumber: Data Sekunder Diolah, 2021

Berdasarkan tabel 3 di atas dapat diketahui bahwa pada uji normalitas dengan menggunakan alat uji kolmogorov sminov $Z$, dapat dilihat bahwa nilai signifikansi (Asymp.Sig2-tailed) sebesar 0,170. Karena signifikansi lebih dari 0,05 $(0,170>0,05)$. Hal ini menunjukkan bahwa data yang diambil terdistribusi normal.

\subsubsection{Hasil Uji Multikolinearitas}

Adanya gejala multikolinearitas dapat dilihat dari nilai Variance Inflation Factor (VIF) dengan batas VIF adalah 10. Apabila VIF $>10=$ terjadi multikolinearitas. Apabila VIF $<10=$ tidak terjadi multikolinearitas. Hasil pengujian terhadap multikolinearitas pada penelitian ini dapat dilihat pada tabel 5 sebagai berikut:

\section{Tabel 4 Hasil Uji Multikolinearitas}

Coefficients $^{\mathrm{a}}$

\begin{tabular}{|rl|r|r|r|r|r|}
\hline \multirow{2}{*}{ Model } & \multicolumn{2}{|c|}{$\begin{array}{c}\text { Unstandardized } \\
\text { Coefficients }\end{array}$} & $\begin{array}{c}\text { Standardized } \\
\text { Coefficients }\end{array}$ & \multicolumn{2}{c|}{ Collinearity Statistics } \\
\cline { 3 - 7 } & \multicolumn{1}{|c|}{ B } & Std. Error & Beta & Tolerance & \multicolumn{1}{c|}{ VIF } \\
\hline 1 & (Constant) & 115,048 & 27,706 & & & \\
& Interest.Rate & $-42,715$ & 16,035 & $-4,174$ &, 002 & 403,292 \\
LNMoney.Supply &,- 771 & 1,671 &,- 041 &, 771 & 1,298 \\
& Inflation.Rate &,- 673 &, 518 &,- 145 &, 490 & 2,041 \\
& Risk.Premium & $-35,300$ & 16,183 & $-3,458$ &, 002 & 412,881 \\
\hline
\end{tabular}

a. Dependent Variable: Stock.Market.Performance

Sumber: Data sekunder Diolah, 2021

Berdasarkan tabel 4 di atas dapat diketahui bahwa tidak ada satupun variabel bebas yang memiliki nilai VIF lebih dari 10. Dari hasil ini maka dapat disimpulkan bahwa semua variabel bebas yang dipakai dalam penelitian ini lolos uji gejala multikolinearitas. 


\subsubsection{Hasil Uji Heeroskedastisitast}

Uji heteroskedastisitas adalah keadaan di mana dalam model regresi terjadi ketidaksamaan varians dari residual pada satu pengamatan ke pengamatan yang lain. Model regresi yang baik adalah tidak terjadi heteroskedastisitas. Pada penelitian ini untuk mendeteksi adanya heteroskedastisitas pada data dilakukan dengan melihat grafik scatter plot. Dasar pengambilan keputusan dalam uji heteroskedastisitas dengan grafik scatter plot:

1. Jika terdapat pola tertentu pada grafik scatter plot, seperti titik-titik yang membentuk pola yang teratur (bergelombang, menyebar kemudian menyempit), maka terjadi heteroskedastisitas.

2. Jika tidak ada pola yang jelas serta titik-titik menyebar, maka indikasinya adalah tidak terjadi heteroskedastisitas.

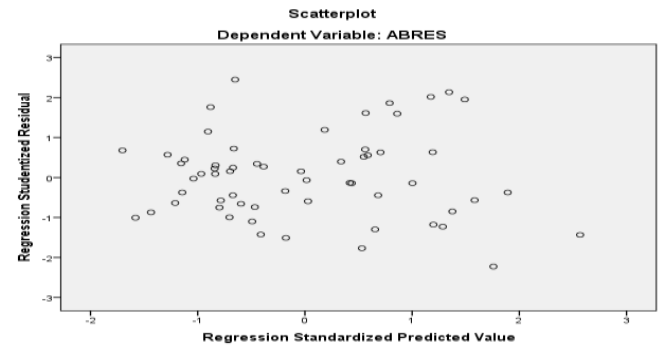

Sumber: Data Primer Diolah, 2021

\section{Gambar 2 Hasil Pengujian Heteroskedastisitas}

Dari gambar di atas dapat diketahui bahwa titik-titik menyebar secara acak serta tersebar baik di atas maupun di bawah angka 0 pada sumbu Y. maka dapat disimpulkan bahwa tidak terjadi heteroskedastisitas pada model regresi dalam penelitian ini.:

\subsubsection{Hasil Uji Autokorelasi}

Uji ini bertujuan untuk melihat apakah dalam suatu model linear ada korelasi antar kesalahan pengganggu pada periode $t$ dengan kesalahan periode $t-1$ (sebelumnya). Model regresi yang baik adalah yang bebas dari autokorelasi. Masalah autokorelasi umumnya terjadi pada regresi yang datanya time series. Untuk mendeteksi masalah autokorelasi dapat dilakukan dengan menggunakan uji Durbin Watson. Secara umum panduan mengenai angka DurbinWatson dapat diambil patokan sebagai berikut :

1) angka D-W dibawah -2 berarti ada autokorelasi positif.

2) angka $D-W$ di antara -2 sampai +2 , berarti tidak ada autokorelasi.

3) angka $\mathrm{D}-\mathrm{W}$ di atas +2 berarti ada autokorelasi negatif.

Tabel 5 Hasil Uji Autokorelasi Model Summary ${ }^{b}$

\begin{tabular}{|l|r|r|r|r|r|}
\hline Model & R & R Square & $\begin{array}{c}\text { Adjusted R } \\
\text { Square }\end{array}$ & $\begin{array}{c}\text { Std. Error of the } \\
\text { Estimate }\end{array}$ & Durbin-Watson \\
\hline 1 &, $816^{\mathrm{a}}$ &, 665 &, 641 & 3,81927 &, 166 \\
\hline
\end{tabular}

Sumber: Data Sekunder Diolah, 2021

Berdasarkan tabel 5 di atas dapat diketahui bahwa nilai statistik D-W sebesar 0,166. Angka ini terletak diantara -2 dan +2 , dari pengamatan ini dapat disimpulkan bahwa tidak terjadi autokorelasi positif maupun autokorelasi negatif dalam penelitian ini.

\subsection{Hasil Analisis Regresi Linier Berganda}

4.3.1 Hasil Analisis Regresi Linier Berganda Model I

Analisis regresi linier berganda digunakan untuk mengetahui pengaruh variabel bebas terhadap variabel terikat, dengan variabel intervening di mana variabel bebasnya meliputi Interet Rate (X1), Money Supply (X2) dan Inflation Rate (X3) serta variabel terikatnya adalah Risk Premium (Z). Di bawah ini adalah hasil dari analisis tersebut : 
Tabel 6 Hasil Uji Regresi Linier Berganda Model 1 Coefficients $^{\mathrm{a}}$

\begin{tabular}{|c|c|c|c|c|c|c|}
\hline \multirow{2}{*}{\multicolumn{2}{|c|}{ Model }} & \multicolumn{2}{|c|}{$\begin{array}{c}\text { Unstandardized } \\
\text { Coefficients }\end{array}$} & \multirow{2}{*}{$\begin{array}{c}\begin{array}{c}\text { Standardized } \\
\text { Coefficients }\end{array} \\
\text { Beta }\end{array}$} & \multirow[b]{2}{*}{$\mathrm{T}$} & \multirow[b]{2}{*}{ Sig. } \\
\hline & & B & Std. Error & & & \\
\hline \multirow[t]{4}{*}{1} & (Constant) &, 159 & ,228 & & ,700 & ,487 \\
\hline & Interest.Rate &,- 989 & ,009 &,- 986 & $-114,705$ &, 000 \\
\hline & LNMoney.Supply &,- 012 &, 014 &,- 006 &,- 853 & ,397 \\
\hline & Inflation.Rate &,- 011 &, 004 &,- 024 & $-2,656$ & 010 \\
\hline
\end{tabular}

a. Dependent Variable: Risk.Premium

Sumber: Data Sekunder Diolah, 2021

Berdasarkan tabel 6 di atas maka dapat dirumuskan persamaan regresi linier sebagai berikut:

$$
\begin{array}{|c|}
\hline Z=0,159-0,989 X_{1}-0,012 X_{2}-0,011 X_{3}+e \\
Z=-3,143-0,056 X_{1}+0,587 X_{2}+0,256 X 3+e
\end{array}
$$

Interprestasi berdasarkan persamaan di mana risk premium dijadikan sebagai variabel intervening tersebut dapat diartikan sebagai berikut :

a. Konstanta sebesar 0,159 artinya jika interest rate, money supply dan inflation rate diabaikan atau bernilai 0 , maka besarnya risk premium adalah sebesar konstanta 0,159 .

b. Koefisien regresi variabel interest rate sebesar $-0,989$. Hal ini berarti bahwa setiap kenaikan variabel interest rate sebesar satu (1) satuan dengan asumsi money supply dan inflation rate diabaikan atau bernilai nol (0) maka akan terjadi penurunan risk premium sebesar 0,989 .

c. Koefisien regresi variabel money supply sebesar $-0,012$. Hal ini berarti bahwa setiap kenaikan variabel money supply sebesar satu (1) satuan dengan asumsi interest rate dan inflation rate diabaikan atau bernilai nol (0) maka akan terjadi penurunan risk premium sebesar 0,012 .

d. Koefisien regresi inflation ratesebesar -0,011. Hal ini berarti bahwa setiap kenaikan satu (1) satuan dengan asumsi interest rate dan money supply diabaikan atau bernilai nol (0) maka akan terjadi penurunan risk premium sebesar 0,011 .

\subsubsection{Hasil Uji Parsial Model I}

Uji t dimaksud untuk menguji signifikan pengaruh variabel bebas dan terikat secara parsial. Di mana pengujian ini membandingkan antara probabilitas signifikan dengan alpha 0,05 . Dari hasil pengujian ini bila probabilitas signifikan lebih kecil dari pada alpha 0,05 maka diperoleh $\mathrm{H}_{\mathrm{o}}$ ditolak dan $\mathrm{H}_{\mathrm{a}}$ diterima, berarti ada hubungan dan bila probabilitas signifikan lebih besar dari pada alpha 0,05 maka $\mathrm{H}_{\mathrm{o}}$ diterima dan $\mathrm{H}_{\mathrm{a}}$ ditolak, berarti tidak ada hubungan. Derajat kebebasan (df) n-k-1 yaitu $26-3-1=22$ (n adalah jumlah sampel dan k adalah jumlah variabel independen) sehingga hasil yang diperoleh untuk $\mathrm{t}_{\text {tabel }}$ sebesar 2,073. Berdasarkan dari hasil pengujian hipotesis secara parsial, dapat dilihat pada tabel uji analisis linier berganda model I (tabel 4.6) yang dapat disimpulkan sebagai berikut :

1. Variabel Interest Rate $\left(\mathrm{X}_{1}\right)$

$\mathrm{H}_{\mathrm{o}}: \mathrm{b} 1=0$ : Interest rate $\left(\mathrm{X}_{1}\right)$ tidak berpengaruh signifikan terhadap risk premium (Z).

$\mathrm{H}_{1}$ : b1 > 0 : Interest rate $\left(\mathrm{X}_{1}\right)$ berpengaruh signifikan terhadap risk premium $(\mathrm{Z})$

Hasil pengujian SPSS pada tabel 4.6 diperoleh $t_{\text {hitung }}>$ dari $t_{\text {tabel }}(-114,705<$ $2,073)$ dengan tingkat signifikan $(0,000<0,05)$. Berdasarkan keterangan tersebut maka $\mathrm{H}_{0}$ ditolak dan $\mathrm{H}_{\mathrm{a}}$ diterima. Dengan demikian, maka hipotesis pertama diterima.

2. Variabel Money Supply $\left(\mathrm{X}_{2}\right)$

$\mathrm{H}_{\mathrm{o}}: \mathrm{b} 2=0$ : Money supply $\left(\mathrm{X}_{2}\right)$ tidak berpengaruh signifikan terhadap risk premium (Z).

$\mathrm{H}_{2}$ : b2 > 0 : Money supply $\left(\mathrm{X}_{2}\right)$ berpengaruh signifikan terhadap risk premium $(\mathrm{Z})$ 
Hasil pengujian SPSS pada tabel 4.6 diperoleh $t_{\text {hitung }}<$ dari $t_{\text {tabel }}(-0,853<$ $2,073)$ dengan tingkat signifikan $(0,397>0,05)$. Berdasarkan keterangan tersebut maka $\mathrm{H}_{0}$ diterima dan $\mathrm{H}_{\mathrm{a}}$ ditolak. Dengan demikian, maka hipotesis kedua ditolak.

3. Variabel Inflation Rate $\left(\mathrm{X}_{3}\right)$

$\mathrm{H}_{\mathrm{o}}$ : b3 = 0 : Inflation rate $\left(\mathrm{X}_{3}\right)$ tidak berpengaruh signifikan terhadap risk premium (Z).

$\mathrm{H}_{3}$ : b3 > 0 : Inflation rate $\left(\mathrm{X}_{3}\right)$ berpengaruh signifikan terhadap risk premium $(\mathrm{Z})$

Hasil pengujian SPSS pada tabel 4.6 diperoleh $t_{\text {hitung }}>$ dari $t_{\text {tabel }}(-2,656>$ $2,073)$ dengan tingkat signifikan $(0,010<0,05)$. Berdasarkan keterangan tersebut maka $\mathrm{H}_{0}$ ditolak dan $\mathrm{H}_{\mathrm{a}}$ diterima. Dengan demikian, maka hipotesis ketiga diterima.

\subsubsection{Hasil Uji Simultan Model I}

Uji F menggunakan taraf signifikan 0,05 (uji 2 sisi) dengan derajat kebebasan 95\%, alpha $=5 \%$, df 1 (jumlah variabel-1) atau $3-1=2$, dan df $2(\mathrm{n}-\mathrm{k}-1)$ atau 26-3-1 = 22, maka hasil yang diperoleh untuk $\mathrm{F}_{\text {tabel }}$ sebesar 3,05.

Uji $F$ di maksud untuk menguji hipotesis dari penelitian yang menyatakan variabel interest rate $\left(\mathrm{X}_{1}\right)$, money supply $\left(\mathrm{X}_{2}\right)$ dan inflation rate $\left(\mathrm{X}_{3}\right)$ terhadap risk premium $(\mathrm{Z})$. Hasil pengujian hipotesis secara bersama-sama dapat dilihat pada tabel 4.7 sebagai berikut :

\section{Tabel 7 Hasil Pengujian Secara Simultan (Uji-F)-1}

\begin{tabular}{|c|c|c|c|c|c|c|}
\hline \multicolumn{7}{|c|}{ ANOVA $^{\mathrm{a}}$} \\
\hline & Model & Sum of Squares & Df & Mean Square & $\mathrm{F}$ & Sig. \\
\hline \multirow[t]{3}{*}{1} & Regression & 22,942 & 3 & 7,647 & 7688,450 &, $000^{6}$ \\
\hline & Residual & ,056 & 56 & , 001 & & \\
\hline & Total & 22,998 & 59 & & & \\
\hline
\end{tabular}

Sumber: Data Sekunder Diolah, 2021

Berdasarkan tabel 7 di atas dapat diketahui bahwa nilai $\mathrm{F}_{\text {hitung }} 7688,450>\mathrm{F}_{\text {tabel }} 3,05$ dan nilai signifikansi $\mathrm{F} 0,000<0,05$ sehingga dapat disimpulkan bahwa secara bersama-sama interest rate (X1), money supply (X2) dan inflation rate (X3) terhadap risk premium $(\mathrm{Z})$ pada perusahaan LQ45 periode tahun 2015-2019. Maka dapat disimpulkan bahwa $\mathrm{H}_{0}$ ditolak dan $\mathrm{H}_{\mathrm{a}}$ diterima.

\subsubsection{Hasil Analisis Regresi Linier Berganda Model II}

Analisis regresi linier berganda digunakan untuk mengetahui pengaruh variabel bebas terhadap variabel terikat, dengan variabel intervening di mana variabel bebasnya meliputi interest rate $\left(\mathrm{X}_{1}\right)$, money supply $\left(\mathrm{X}_{2}\right)$, inflation rate $\left(\mathrm{X}_{3}\right)$ dan risk premium $(\mathrm{Z})$, sedangkan variabel terikatnya yaitu stock market performance $(\mathrm{Y})$. Di bawah ini adalah hasil dari analisis tersebut :

Tabel 8 Hasil Uji Regresi Linier Berganda model II Coefficients $^{\mathrm{a}}$

\begin{tabular}{|c|c|c|c|c|c|c|}
\hline & \multirow[t]{2}{*}{ Model } & \multicolumn{2}{|c|}{ Unstandardized Coefficients } & $\begin{array}{l}\text { Standardized } \\
\text { Coefficients }\end{array}$ & \multirow[t]{2}{*}{$\mathrm{T}$} & \multirow[t]{2}{*}{ Sig. } \\
\hline & & $\mathrm{B}$ & Std. Error & Beta & & \\
\hline \multirow[t]{5}{*}{1} & (Constant) & 115,048 & 27,706 & & 4,153 & , 000 \\
\hline & Interest.Rate & $-42,715$ & 16,035 & $-4,174$ & $-2,664$ & 010 \\
\hline & LNMoney.Supply &,- 771 & 1,671 &,- 041 &,- 461 & ,647 \\
\hline & Inflation.Rate &,- 673 &, 518 &,- 145 & $-1,301$ & ,199 \\
\hline & Risk.Premium & $-35,300$ & 16,183 & $-3,458$ & $-2,181$ & ,033 \\
\hline
\end{tabular}

a. Dependent Variable: Stock.Market.Performance

Sumber: Data Primer Diolah, 2021

Berdasarkan tabel 8 di atas maka dapat dirumuskan persamaan regresi sebagai berikut:

$$
\mathrm{Y}=115,048-42,715 \mathrm{X} 1-0,771 \mathrm{X} 2-0,673 \mathrm{X} 3-35,300 \mathrm{Z}+\mathrm{e}
$$


Interprestasi berdasarkan persamaan tersebut di mana stock market performance dijadikan sebagai variabel terikat dapat diartikan sebagai berikut :

a. Konstanta sebesar 115,048 artinya jika interest rate, money supply, inflation rate dan risk premium diabaikan atau bernilai 0 , maka besarnya stock market performance adalah sebesar konstanta 115,048.

b. Koefisien regresi variabel interest rate sebesar $-42,715$. Hal ini berarti bahwa setiap kenaikan variabel interest rate sebesar satu (1) satuan dengan asumsi money supply, inflation rate dan risk premium diabaikan atau bernilai nol (0) maka akan terjadi penurunan stock market performancesebesar 42,715.

c. Koefisien regresi variabel money supply sebesar -0,771. Hal ini berarti bahwa setiap kenaikan variabel money supply sebesar satu (1) satuan dengan asumsi interest rate, inflation rate dan risk premium diabaikan atau bernilai nol (0) maka akan terjadi penurunan stock market performance sebesar 0,771.

d. Koefisien regresi variabel inflation rate sebesar -0,673. Hal ini berarti bahwa setiap kenaikan variabel inflation rate sebesar satu (1) satuan dengan asumsi interest rate, money supply dan risk premium diabaikan atau bernilai nol (0) maka akan terjadi penurunan stock market performancesebesar 0,673 .

e. Koefisien regresi variabel risk premium sebesar -35,300. Hal ini berarti bahwa setiap kenaikan variabel risk premium sebesar satu (1) satuan dengan asumsi interest rate, money supply dan inflation rate diabaikan atau bernilai nol (0) maka akan terjadi penurunan stock market performance sebesar 35,300.

\subsubsection{Hasil Uji Parsial Model II}

Uji t dimaksud untuk menguji signifikan pengaruh variabel bebas dan terikat secara parsial. Di mana pengujian ini membandingkan antara probabilitas signifikan dengan alpha 0,05. Dari hasil pengujian ini bila probabilitas signifikan lebih kecil dari pada alpha 0,05 maka diperoleh $\mathrm{H}_{\mathrm{o}}$ ditolak dan $\mathrm{H}_{\mathrm{a}}$ diterima, berarti ada hubungan dan bila probabilitas signifikan lebih besar daripada alpha 0,05 maka $\mathrm{H}_{\mathrm{o}}$ diterima dan $\mathrm{H}_{\mathrm{a}}$ ditolak, berarti tidak ada hubungan. Derajat kebebasan (df) n-k-1 yaitu 26-4-1=21 (n adalah jumlah sampel dan k adalah jumlah variabel independen) sehingga hasil yang diperoleh untuk $\mathrm{t}_{\text {-tabel }}$ sebesar 2,079.

Berdasarkan hasil pengujian hipotesis secara parsial dapat dilihat pada tabel uji analisis linier berganda model II (tabel 9) yang dapat disimpulkan sebagai berikut :

1. Variabel Interest Rate $\left(\mathrm{X}_{1}\right)$

$\mathrm{H}_{\mathrm{o}}: \mathrm{b} 4=0$ : Interest rate $\left(\mathrm{X}_{1}\right)$ tidak berpengaruh signifikan terhadap stock market performance $(\mathrm{Y})$.

$\mathrm{H}_{4}$ : b4 > 0 : Interest rate $\left(\mathrm{X}_{1}\right)$ berpengaruh signifikan terhadap stock market performance $(\mathrm{Y})$

Hasil pengujian SPSS pada tabel 4.8 diperoleh $t_{\text {hitung }}>$ dari $t_{\text {tabel }}(-42,715>$ $2,079)$ dengan tingkat signifikan $(0,010<0,05)$. Berdasarkan keterangan tersebut maka $\mathrm{H}_{0}$ ditolak dan $\mathrm{H}_{\mathrm{a}}$ diterima. Dengan demikian, maka hipotesis ke empat diterima.

2. Variabel Money Supply $\left(\mathrm{X}_{2}\right)$

$\mathrm{H}_{\mathrm{o}}: \mathrm{b} 5=0$ : Money supply $\left(\mathrm{X}_{2}\right)$ tidak berpengaruh signifikan terhadap stock market performance $(\mathrm{Y})$.

$\mathrm{H}_{5}: \mathrm{b} 5>0$ : Money supply $\left(\mathrm{X}_{2}\right)$ berpengaruh signifikan terhadap stock market performance $(\mathrm{Y})$

Hasil pengujian SPSS pada tabel 4.8 diperoleh $\mathrm{t}_{\text {hitung }}<$ dari $\mathrm{t}_{\text {tabel }}(-0,461>2,079)$ dengan tingkat signifikan $(0,647>0,05)$. Berdasarkan keterangan tersebut maka $\mathrm{H}_{0}$ diterima dan $\mathrm{H}_{\mathrm{a}}$ ditolak. Dengan demikian, maka hipotesis ke lima ditolak.

3. Variabel Inflation Rate $\left(\mathrm{X}_{3}\right)$

$\mathrm{H}_{\mathrm{o}}$ : b6 $=0$ : Inflation rate $\left(\mathrm{X}_{3}\right)$ tidak berpengaruh signifikan terhadap stock market performance $(\mathrm{Y})$

$\mathrm{H}_{6}$ : b6 >0 : Inflation rate $\left(\mathrm{X}_{3}\right)$ berpengaruh signifikan terhadp stock market performance $(\mathrm{Y})$

Hasil pengujian SPSS pada tabel 4.8 diperoleh $\mathrm{t}_{\text {hitung }}<$ dari $\mathrm{t}_{\text {tabel }}(-1,301>2,079)$ dengan tingkat signifikan $(0,199>0,05)$. Berdasarkan keterangan tersebut maka $\mathrm{H}_{0}$ diterima dan $\mathrm{H}_{\mathrm{a}}$ ditolak. Dengan demikian, maka hipotesis ke enam ditolak. 
4. Variabel Risk Premium (Z)

$\mathrm{H}_{\mathrm{o}}: \mathrm{b} 7=0$ : Risk premium $(\mathrm{Z})$ tidak berpengaruh signifikan terhadap stock market performance $(\mathrm{Y})$

$\mathrm{H}_{7}: \mathrm{b} 7>0$ : Risk premium $(\mathrm{Z})$ berpengaruh signifikan terhadap stock market performance $(\mathrm{Y})$

Hasil pengujian SPSS pada tabel 4.8 diperoleh $\mathrm{t}_{\text {hitung }}>$ dari $\mathrm{t}_{\text {tabel }}(-2,181>2,079)$

dengan tingkat signifikan $(0,033<0,05)$. Berdasarkan keterangan tersebut maka $\mathrm{H}_{0}$ ditolak dan $\mathrm{H}_{\mathrm{a}}$ diterima. Dengan demikian, maka hipotesis ke tujuh diterima.

\subsubsection{Hasil Uji Simultan Model II}

Uji F menggunakan taraf signifikan 0,05 (uji 2 sisi) dengan derajat kebebasan 95\%, alpha $=5 \%$, df 1 (jumlah variabel-1) atau $4-1=3$, dan df 2 (n-k-1) $26-4-1=21$, maka hasil yang diperoleh untuk $\mathrm{F}_{\text {tabel }}$ sebesar 2,84.

Uji $\mathrm{F}$ dimaksud untuk menguji hipotesis dari penelitian yang menyatakan variabel interest rate $\left(\mathrm{X}_{1}\right)$, money supply $\left(\mathrm{X}_{2}\right)$, inflation rate $\left(\mathrm{X}_{3}\right)$ dan risk premium $(\mathrm{Z})$ terhadap stock market performance $(\mathrm{Y})$. Hasil pengujian hipotesis secara bersama-sama dapat dilihat pada tabel 10 sebagai berikut :

Tabel 9 Hasil Pengujian Secara Simultan (Uji-F)-1

ANOVA $^{a}$

\begin{tabular}{|ll|r|r|r|r|r|}
\hline \multicolumn{1}{|c|}{ Model } & Sum of Squares & \multicolumn{1}{c|}{ df } & Mean Square & F & \multicolumn{1}{c|}{ Sig. } \\
\hline Regression & 1593,573 & 4 & 398,393 & 27,312 &, $000^{6}$ \\
& Residual & 802,277 & 55 & 14,587 & & \\
& Total & 2395,850 & 59 & & & \\
\hline
\end{tabular}

Sumber: Data Sekunder Diolah, 2021

Berdasarkan tabel 9 di atas dapat diketahui bahwa bahwa $\mathrm{F}_{\text {hitung }} 27,312>\mathrm{F}_{\text {tabel }} 2,84$ dan nilai signifikansi $\mathrm{F}$ sebesar $0,000<0,05$ sehingga dapat disimpulkan bahwa interest rate $\left(\mathrm{X}_{1}\right)$, money supply $\left(\mathrm{X}_{2}\right)$, inflation rate $\left(\mathrm{X}_{3}\right)$ dan risk premium $(\mathrm{Z})$ secara bersama-sama berpengaruh terhadap stock market performance $(\mathrm{Y})$ pada perusahaan LQ45 periode 20152019. Maka dapat disimpulkan bahwa $\mathrm{H}_{0}$ ditolak dan $\mathrm{H}_{\mathrm{a}}$ diterima.

\subsubsection{Hasil Analisis Jalur}

Pada tahap ini kita akan menghitung koefesien jalur interest rate, money supply dan inflation rate terhadap risk premium, serta koefesien jalur interest rate, money supply, inflation rate dan risk premium terhadap stock market performance yang dirangkum dalam bentuk diagram jalur. Berdasarkan hasil uji statistik pada tabel analisis regresi linier berganda model I dan analisis regresi linier berganda model II maka dapat dirumuskan diagram jalur dan persamaan sebagai berikut :

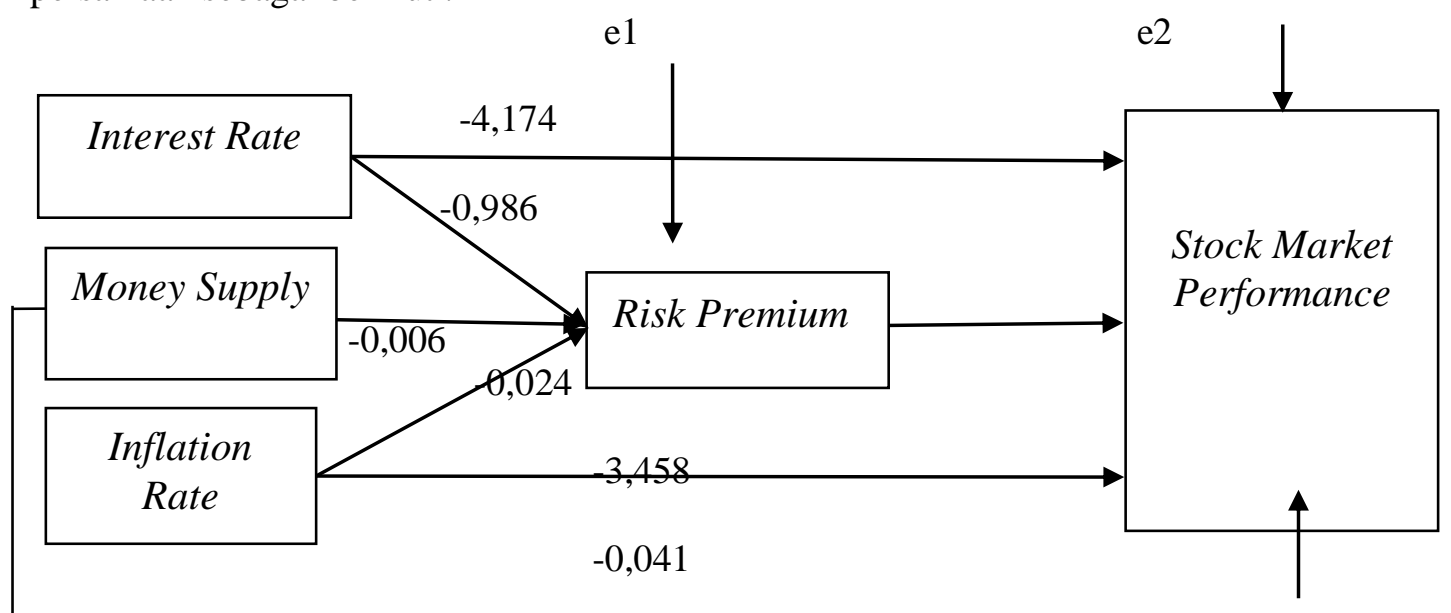

Gambar 3 Diagram Jalur

Persamaan I:

$$
Z=-0,989 X_{1}-0,006 X_{2}-0,024 X_{3}+e
$$


Persamaan II:

$$
Y=-4,174 X_{1}-0,041 X_{2}-0,145 X_{3}-3,458 Z+e
$$

Berdasarkan persamaan I dan persamaan II dari diagram jalur maka dapat dihitung pengaruh langsung dan tidak langsung ke dalam tabel 11 sebagai berikut :

Tabel 10 Perhitungan Pengaruh Langsung dan Pengaruh Tidak Langsung

\begin{tabular}{|l|c|c|c|}
\hline \multicolumn{1}{|c|}{ Pengaruh Variabel } & Langsung & Tidak Langsung & Total \\
\hline $\begin{array}{l}\text { Interest rate terhadap stock } \\
\text { market performance }\end{array}$ & $-4,174$ & $-0,755$ \\
\hline $\begin{array}{l}\text { Interest rate terhadap stock } \\
\text { market performance melalui risk } \\
\text { premium }\end{array}$ & - & $-0,989 \times-3,458=3,419$ & \\
\hline $\begin{array}{l}\text { Money supply terhadap stock } \\
\text { market performance }\end{array}$ & $-0,145$ & - & $-0,124$ \\
$\begin{array}{l}\text { Money supply terhadap stock } \\
\text { market performance melalui risk } \\
\text { premium }\end{array}$ & - & $-0,006 \times-3,458=0,021$ & \\
\hline $\begin{array}{l}\text { Inflation rate terhadap stock } \\
\text { market performance }\end{array}$ & $-0,041$ & & $-0,042$ \\
\hline $\begin{array}{l}\text { Inflation rate terhadap stock } \\
\text { market performance melalui risk } \\
\text { premium }\end{array}$ & - & $-0,024 \times-3,458=0,082$ & \\
\hline
\end{tabular}

Sumber: Data Sekunder Diolah, 2021

Berdasarkan tabel 10 perhitungan pengaruh langsung dan pengaruh tidak langsung di atas, dapat di simpulkan sebagai berikut:

1. Pengaruh interest rate $\left(\mathrm{X}_{1}\right)$ terhadap stock market performance $(\mathrm{Y})$ melalui risk premium $(\mathrm{Z})$

Hasil perhitungan menunjukkan bahwa pengaruh tidak langsung interest rate terhadap stock market performance melalui risk premium lebih kecil dibandingkan dengan pengaruh langsung interest rate terhadap nilai risk premium $(-3,419<4,174)$ sehingga dapat disimpulkan bahwa risk premium tidak mampu memediasi pengaruh antara interest rate terhadap stock market performance.

2. Pengaruh money supply $\left(\mathrm{X}_{2}\right)$ terhadap stock market performance $(\mathrm{Y})$ melalui risk premium $(\mathrm{Z})$

Hasil perhitungan menunjukkan bahwa pengaruh tidak langsung money supply terhadap stock market performance melalui risk premium lebih kecil dibandingkan dengan pengaruh langsung money supply terhadap nilai risk premium $(0,124<$ 0,145 ), sehingga dapat disimpulkan bahwa risk premium tidak mampu memediasi pengaruh antara money supply terhadap stock market performance.

3. Pengaruh inflation rate $\left(\mathrm{X}_{3}\right)$ terhadap stock market performance $(\mathrm{Y})$ melalui risk premium $(\mathrm{Z})$

Hasil perhitungan menunjukkan bahwa pengaruh tidak langsung inflation rate terhadap stock market performance melalui risk premium lebih besar dibandingkan dengan pengaruh langsung interest rate terhadap nilai risk premium $(0,082>-0,041)$, sehingga dapat disimpulkan bahwa risk premium mampu memediasi pengaruh antara inflation rate terhadap stock market performance.

\subsubsection{Koefisien Determinasi $R$-Square (R2)}

Analisis koefisien determinasi $\mathrm{R}^{2}$ digunakan untuk mengetahui seberapa besar kontribusi variabel-variabel bebas dalam menjelaskan variabel terikat.

\subsubsection{Hasil Uji R-Square Model I} berikut :

Hasil uji koefisien determinasi pada model regresi satu dapat dilihat pada tabel 11 
Tabel 11 Koefisien Determinasi Model I

Model Summary

\begin{tabular}{|l|r|r|r|r|}
\hline Model & \multicolumn{1}{|c|}{ R } & R Square & $\begin{array}{c}\text { Adjusted R } \\
\text { Square }\end{array}$ & $\begin{array}{c}\text { Std. Error of } \\
\text { the Estimate }\end{array}$ \\
\hline 1 &, $999^{\mathrm{a}}$ &, 998 &, 997 &, 03154 \\
\hline
\end{tabular}

Sumber: Data Sekunder Diolah, 2021

Berdasarkan tabel 11 di atas dapat diketahui bahwa nilai Adjusted $R$ Square sebesar 0,997 atau $99,7 \%$, hal ini menunjukkan bahwa persentase sumbangan variabel interest rate $\left(\mathrm{X}_{1}\right)$, money supply $\left(\mathrm{X}_{2}\right)$ dan inflation rate $\left(\mathrm{X}_{3}\right)$ terhadap risk premium $(\mathrm{Z})$ sebesar 0,997 atau $99,7 \%$. Sedangkan sisanya sebesar $0,3 \%$ dipengaruhi oleh variabel lain di luar penelitian ini.

\subsubsection{Hasil Uji R-Square Model II} berikut :

Hasil uji koefisien determinasi pada model regresi dua dapat dilihat pada tabel 12

Tabel 12 Koefisien Determinasi Model II Model Summary

\begin{tabular}{|l|r|r|r|r|}
\hline Model & R & R Square & \multicolumn{1}{|c|}{$\begin{array}{c}\text { Adjusted R } \\
\text { Square }\end{array}$} & $\begin{array}{c}\text { Std. Error of } \\
\text { the Estimate }\end{array}$ \\
\hline 1 &, $816^{\mathrm{a}}$ &, 665 &, 641 & 3,81927 \\
\hline
\end{tabular}

Sumber: Data Sekunder Diolah, 2021

Berdasarkan tabel 12 di atas dapat diketahui bahwa nilai Adjusted $R^{2}$ sebesar 0,641 atau $64,1 \%$, hal ini menunjukkan bahwa persentase sumbangan variabel interest rate $\left(\mathrm{X}_{1}\right)$, money supply $\left(\mathrm{X}_{2}\right)$, inflation rate $\left(\mathrm{X}_{3}\right)$ dan risk premium $(\mathrm{Z})$ terhadap stock market performance $(\mathrm{Y})$ sebesar 0,641 atau $64,1 \%$. Sedangkan sisanya sebesar 35,9\% dipengaruhi oleh variabel lain di luar penelitian ini.

\section{Kesimpulan}

Berdasarkan kajian, hasil analisa statistik penelitian dan pembahasan yang telah dipaparkan sebelumnya, maka dapat ditarik kesimpulan sebagai berikut :

1. Terdapat pengaruh interest rate terhadap risk premium pada Bank Indonesia (BI) periode 2015-2019.

2. Tidak terdapat pengaruh money supply terhadap risk premium pada Bank Indonesia (BI) periode 2015-2019.

3. Terdapat pengaruh inflation rate terhadap risk premium pada Bank Indonesia (BI) periode 2015-2019.

4. Terdapat pengaruh interest rate, money supply, inflation rate terhadap risk premium pada Bank Indonesia (BI) periode 2015-2019.

5. Terdapat pengaruh interest rate terhadap stock market performance pada Bank Indonesia (BI) periode 2015-2019.

6. Tidak terdapat pengaruh money supply terhadap stock market performance pada Bank Indonesia (BI) periode 2015-2019.

7. Tidak terdapat pengaruh inflation rate terhadap stock market performance pada Bank Indonesia (BI) periode 2015-2019.

8. Terdapat pengaruh risk premium terhadap stock market performance pada Bank Indonesia (BI) periode 2015-2019.

9. Terdapat pengaruh interest rate, money supply, inflation rate dan risk premium terhadap stock market performance pada Bank Indonesia (BI) periode 2015-2019.

10. Risk premium tidak dapat memediasi pengaruh interest rate terhadap stock market performance pada Bank Indonesia (BI) periode 2015-2019.

11. Risk premium tidak dapat memediasi pengaruh money supply terhadap stock market performance pada Bank Indonesia (BI) periode 2015-2019.

12. Risk premium dapat memediasi pengaruh inflation rate terhadap stock market performance pada Bank Indonesia (BI) periode 2015-2019. 


\section{Daftar Pustaka}

Aggarwal, P., \& Manish, M. K. (2020). Effect of Oil Fluctuation on Stock Market Return: An Empirical Study from India. International Journal of Energy Economics and Policy, 10(2), 213-217.

Altintas, H., \& Yacouba, K. (2018). Asymmetric Responses of Stock Prices to Money Supply and Oil Prices Shocks in Turkey: New Evidence from a Nonlinear ARDL Approach. International Journal of Economics and Financial Issues, 8(4), 45-53. https://ideas.repec.org/a/eco/journ1/2018-047.html

Anggarini, D. T. (2016). Analisa Jumlah Uang Beredar di Indonesia Tahun 2005-2014. Moneter-Jurnal Akuntansi Dan Keuangan, 3(2).

https://ejournal.bsi.ac.id/ejurnal/index.php/moneter/article/view/1196

Anwar, S., \& A, A. D. (2020). Analisis Pengaruh Inflasi Dan Kurs Terhadap Indeks Saham Syariah Indonesia (Issi) Tahun 2014-2018. I-Finance: A Research Journal on Islamic Finance, 6(1), 7-14. https://doi.org/10.19109//ifinace.v6i1.5288

Augustpaosa Nariman, H. T. (2019). Faktor-Faktor Yang Mempengaruhi Indeks Harga Saham Gabungan. Jurnal Ekonomi, 24(1), 144. https://doi.org/10.24912/je.v24i1.546

Ayu, W. S. Y.; D. N. P. (2017). Pengaruh Nilai Tukar, Suku Bunga Dan Inflasi Terhadap Indkes Harga Saham Gabungan Di Bursa Efek Indonesia. 6(8), 4391-4421.

Azizah Luthfiah, Ismanto Bambang, S. D. S. (2019). Pengaruh Nilai Tukar Rupiah Dan Jumlah Uang Beredar Luas Terhadap Inflasi Di Indonesia Periode 2010 - 2019.

Crystha, A. I. dan A. (2016). Terhadap Harga Saham Perusahaan Indeks Lq45. 15, 44-64.

Diana, I. K. A., \& Dewi, N. P. M. (2019). Analisis Faktor-Faktor Yang Mempengaruhi Nilai Tukar Rupiah Atas Dolar Amerika Serikat Di Indonesia. E-Jurnal EP Unud, 9(8), 1631-1661.

Farida, M., \& Darmawan, A. (2017). Pengaruh Risiko Inflasi, Risiko Suku Bunga, Risiko Valuta Asing, Dan Profitabilitas Terhadap Return Saham. Jurnal Administrasi Bisnis (JAB)|Vol, 5O(1). www.indonesia-investments.com

Ghozali, I. (2016). Aplikasi AnalisisMultivriate dengan Program IBM SPSS.23. Badan Penerbit Universitas Diponegoro.

Ghozali, I. (2018). Aplikasi Analisis Multivariate dengan Program IBM SPSS.25. Penerbit Universitas Diponegoro.

Ghozali, Imam. (2013). Aplikasi Analisis Multivariate dengan Program SPSS (Edisi Ketu). Badan Penerbit Universitas Diponegoro.

Harsono, A. R., \& Worokinasih, S. (2018). Pengaruh Inflasi, Suku Bunga, dan Nilai Tukar Rupiah Terhadap Indeks Harga Saham Gabungan (Studi pada Bursa Efek Indonesia Periode 2013-2017). Jurnal Administrasi Bisnis, 60(2), 102-110. http://administrasibisnis.studentjournal.ub.ac.id/index.php/jab/article/view/2512

Karyani, S. S., \& Darmawan, A. (2020). Pengaruh Risiko Suku Bunga Bi, Risiko Inflasi, Dan Risiko Nilai Mata Uang Terhadap Profitabilitas (Studi Pada Bank Umum Swasta Nasional Devisa Yang Tercatat Di Bei Tahun 2014-2018). Jurnal Administrasi Bisnis (JAB)|Vol, 78(1), 173-180. http://www.ojk.go.id/

Kumalasari, R., Hidayat, R. R., \& Azizah, D. F. (2016). Pengaruh Nilai Tukar, BI Rate, Tingkat Inflasi, dan Pertumbuhan Ekonomi terhadap Indeks Harga Saham Gabungan (Studi Pada Indeks Harga Saham Gabungan di Bei Periode Juli 2005-Juni 2015). Jurnal Administrasi Bisnis, 34(1), 130-137. http://administrasibisnis.studentjournal.ub.ac.id/index.php/jab/article/view/1326

Munawaroh, H., \& Handayani, S. R. (2019). Pengaruh BI Rate, Kurs Rupiah, Tingkat Inflasi, Harga Minyak Dunia, Harga Emas Dunia Terhadap Indeks Harga Saham Gabungan ( IHSG ) ( Studi pada Perusahaan yang Terdaftar Di Bursa Efek Indonesia Periode 2013-2018 ). Jurnal Administrasi Bisnis, 72(1), 27-36.

Noviandi, M. R., Noviandi, J. R., \& ABS, M. K. (2018). Pengaruh Suku Bunga, Tingkat Inflasi, Indeks Harga Saham Gabungan, Dan Pertumbuhan Jumlah Uang Beredar Terhadap Tingkat Pengembalian Reksadana Saham Tahun 2014-2017. Jurnal Ilmiah Riset Manajemen, 7(11). http://www.riset.unisma.ac.id/index.php/jrm/article/view/1276/1275

Noviandi Muhamad Reza, susyanti jeni, abs M. khoiru. (2017). Prodi manajemen. 63-74. http://www.riset.unisma.ac.id/index.php/jrm/article/view/1276

Nugroho, W. I. (2004). Analisis risk premium dan volatility pada indeks harga saham gabungan dan 10 saham industri dengan metode Vector Autoregressive (VAR ). January 1997.

Nurhayati, S. (2017). Analisa Pengaruh Intellectual Capital Terhadap Kinerja Pasar Dan Kinerja Keuangan Pada Perusahaan Lq45 Yang Terdaftar Di Bursa Efek Indonesia Periode Tahun 20102013. Jurnal ASET (Akuntansi Riset), 9(1), 133-172. https://ejournal.upi.edu/index.php/aset/article/view/5260

Nurmala, N. (2018). Analisis Pengembalian Keputusan Investasi Saham Dengan Pendekatan Capital 
Asset Pricing Model (CAPM) pada Perusahaan Perbankan Terdaftar di Bursa Efek Indonesia. BALANCE Jurnal Akuntansi Dan Bisnis, 2(2), 215. https://doi.org/10.32502/jab.v2i2.1173

Otorima, M., \& Kesuma, A. (2016). Pengaruh Nilai Tukar, Suku Bunga, Inflasi, Jumlah Uang Beredar dan PDB terhadap Indeks Harga Saham Gabungan (IHSG) Periode 2005-2015. Jurnal Terapan Manajemen Dan Bisnis, 2(2), 195539. https://www.neliti.com/publications/195539/pengaruh-nilaitukar-suku-bunga-inflasi-jumlah-uang-beredar-dan-pdb-terhadap-ind

Pamungkas, B. C., \& Darmawan, A. (2018). Pengaruh Nilai Tukar USD dan Bursa Asean Terhadap Indeks Harga Saham Gabungan (IHSG) (Studi pada Bursa Efek Indonesia Periode 2014 - 2016). Jurnal Administrasi Bisnis, 60(1), 73-81. http://administrasibisnis.studentjournal.ub.ac.id/index.php/jab/article/view/2483

Rachmawati, Y. (2019). Pengaruh Inflasi dan Suku Bunga Terhadap Harga Saham Pada Perusahaan Perbankan Yang Terdaftar Di LQ45 Bursa Efek Indonesia. Jurnal Media Akuntansi, 1(1). https://jurnal.univpgri-palembang.ac.id/index.php/mediasi/article/view/2368/2173

Rahmatika, N. (2019). Pengaruh Jumlah Uang Beredar, Kurs Us Dollar Dan Indeks Harga Konsumen Terhadap Indeks Harga Saham Sektor Perdagangan Di Bursa Efek Indonesia. Media Ekonomi, 25(2), 93. https://doi.org/10.25105/me.v25i2.4892

Rizqiyana, A., \& Arfianto, E. D. (2019). Pengaruh Ambiguity, Market Risk Premium, Market to Book, Size, dan Momentum terhadap Return Saham pada Perusahaan yang Terdaftar dalam Indeks LQ45 Periode 2017-2018. Diponegoro Journal of Management, 8(4), 70-79. https://ejournal3.undip.ac.id/index.php/djom/article/view/25975

Santoso, S. (2018). Menguasai Statistik dengan SPSS 25. PT Elex Media Komputindo.

Sari, W. I. (2019). Analisis Pengaruh Inflasi, Suku Bunga SBI, Nilai Tukar Terhadap Return LQ 45 dan Dampaknya Terhadap Indeks Harga Saham Gabungan (IHSG) di Bursa Efek Indonesia (BEI). Jurnal SEKURITAS (Saham, Ekonomi, Keuangan Dan Investasi), 3(1), 65. https://doi.org/10.32493/skt.v3i1.3263

Sugiyono. (2011). Metode Penelitian Kuantitatif,Kualitatif dan R\&D. ALFABETA.

Sugiyono. (2012). Memahami Penelitian Kualitatif. ALFABETA.

Sugiyono. (2016). Metode Penelitian Kuantitatif,Kualitatif dan $R \& D$. ALFABETA.

Sugiyono. (2017). Statistika untuk penelitian. ALFABETA.

Sulastri, E., Sasongko, H., \& Manaf, C. (2017). Pengaruh makro ekonomi terhadap harga saham perusahaan subsektor farmasi yang terdaftar di BEI Periode 2008-2015. Jurnal Online Mahasiswa (JOM) Bidang Manajemen, 1(1). https://jom.unpak.ac.id/index.php/ilmumanajemen/article/view/620/571

Wongkar, I. A., Mandey, S. L., \& Tasik, H. H. D. (2018). Analisis Pengaruh Indikator Makro Terhadap Indeks Harga Saham Gabungan Di Bursa Efek Indonesia Periode 2011-2015. Jurnal EMBA: Jurnal Riset Ekonomi, Manajemen, Bisnis Dan Akuntansi, 6(1). https://ejournal.unsrat.ac.id/index.php/emba/article/view/18707/18241

Yuwana, T. H. P. (2019). Pengaruh Suku Bunga Bank Indonesia, Inflasi, Perubahan Kurs Dollar, dan Jumlah Uang Yang Beredar (M2) Terhadap Risk Premium Pada Indeks Harga Saham Gabungan (IHSG). https://dspace.uii.ac.id/handle/123456789/16604 